to geographical distribution and origin of the different forms, in which I am much interested, we may arrange the butterflies as here suggested. But whether we assume eight "families" of the true butterflies, or only four, or only one, the sequence and the principle remain unaltered. The characters by which modern "families" are defined, chiefly by German authors und solche die es werden wollen, are of unequal morphological value, therefore unnatural and, it seems to me, unphilosophical.

\title{
NOTE ON THE LARVA OF THYATIRA PUDENS, GUEN.
}

BY HARRISON G. DYAR, RHINEBECK, N. Y.

As far as I am aware no description of the larva of this insect has been published, and hence I present the following:-

T. pudens.-Mature larva. Head white, with four black spots, two covering the eyes and the others near the summit of the head. A few short, whitish hairs. Body semitransparent, whitish, flecked with opaque white spots on the dorsum and more thinly on the venter. Stigmatal space covered by a blackish shading, more distinct anteriorly ; a darker dorsal line. Spiracles pale brown. Cervical spot whitish, concolorous with body. A few short pale hairs.

The larvæ feed singly on dogwood (Cornus florida), each forming a place of concealment by spinning one or more leaves together by the edges. They mature by the middle of June and pupate in a slight cocoon on the ground, the winter being passed in the pupa state. The pupa has its greatest diameter through the wing cases, the abdominal segments tapering. It is dark brown, approaching black, the brown color showing more distinctly between the segments. Body punctured. Thorax, wing and leg cases finely wrinkled. Cremaster, thick, I $\mathrm{mm}$. long. furnished with stiff, spiny hooks.

This larva well deserves its name of pudens, on account of its modest habits, remaining concealed in its leafy house, and appearing much disturbed if exposed. Its actions recall those of the larva of Endamus tityrus.

The insect has only one brood annually.

Larvæ from Duchess County, N. Y. 